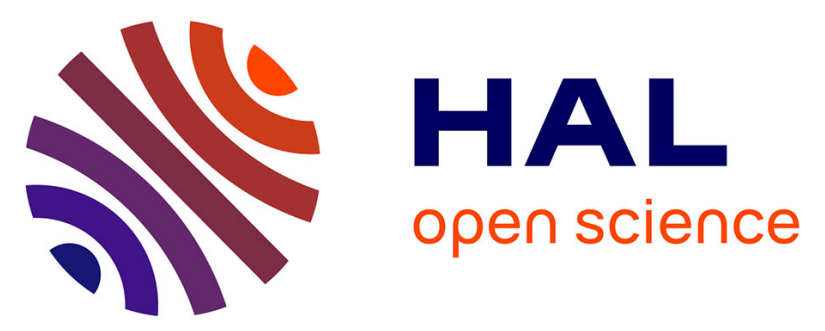

\title{
Non-Nucleophilic Electrolyte Based on Ionic Liquid and Magnesium Bis(diisopropyl)amide for Rechargeable Magnesium-Ion Batteries
}

Lethesh Kallidanthiyil Chellappan, Jannicke Kvello, Julian Richard Tolchard, Paul Inge Dahl, Sidsel Meli Hanetho, Romain Berthelot, Anne Fiksdahl, Kaushik Jayasayee

\section{To cite this version:}

Lethesh Kallidanthiyil Chellappan, Jannicke Kvello, Julian Richard Tolchard, Paul Inge Dahl, Sidsel Meli Hanetho, et al.. Non-Nucleophilic Electrolyte Based on Ionic Liquid and Magnesium Bis(diisopropyl)amide for Rechargeable Magnesium-Ion Batteries. ACS Applied Energy Materials, 2020, 3 (10), pp.9585-9593. 10.1021/acsaem.0c01026 . hal-03001507

\section{HAL Id: hal-03001507 https://hal.science/hal-03001507}

Submitted on 23 Nov 2020

HAL is a multi-disciplinary open access archive for the deposit and dissemination of scientific research documents, whether they are published or not. The documents may come from teaching and research institutions in France or abroad, or from public or private research centers.
L'archive ouverte pluridisciplinaire HAL, est destinée au dépôt et à la diffusion de documents scientifiques de niveau recherche, publiés ou non, émanant des établissements d'enseignement et de recherche français ou étrangers, des laboratoires publics ou privés. 


\title{
Non-Nucleophilic Electrolyte Based on Ionic Liquid and Magnesium Bis(diisopropyl)amide for Rechargeable Magnesium-lon Batteries
}

\author{
Lethesh Kallidanthiyil Chellappan,* Jannicke Kvello, Julian Richard Tolchard, Paul Inge Dahl, \\ Sidsel Meli Hanetho, Romain Berthelot, Anne Fiksdahl, and Kaushik Jayasayee*
}

Cite This: ACS Appl. Energy Mater. 2020, 3, 9585-9593

Read Online

\section{ACCESS |}

Џlll Metrics \& More

Article Recommendations

Supporting Information

ABSTRACT: A non-nucleophilic electrolyte for rechargeable $\mathrm{Mg}$ ion batteries is developed by the reaction of magnesium bis(diisopropyl)amide and 1-ethyl-3-methylimidazolium tetrachloroaluminate ionic liquid in tetrahydrofuran solvent. The electrolyte shows excellent reversibility and Coulombic efficiency for the $\mathrm{Mg}$ deposition/stripping process at room temperature on several working electrodes such as Mo, graphite, and stainless steel. Additionally, the electrolyte shows high anodic stability with Mo as the cathode current collector, with no corrosion detected even after $48 \mathrm{~h}$ at $4.5 \mathrm{~V}$ versus $\left(\mathrm{Mg} / \mathrm{Mg}^{2+}\right)$. An exceptional cyclability in a full cell configuration using a Chevrel phase $\mathrm{Mo}_{6} \mathrm{~S}_{8}$ cathode is achieved with a capacity retention of more than $80 \%$ for over 300 cycles at a $15 \mathrm{~mA} \mathrm{~g}^{-1}$ specific current, making this electrolyte an
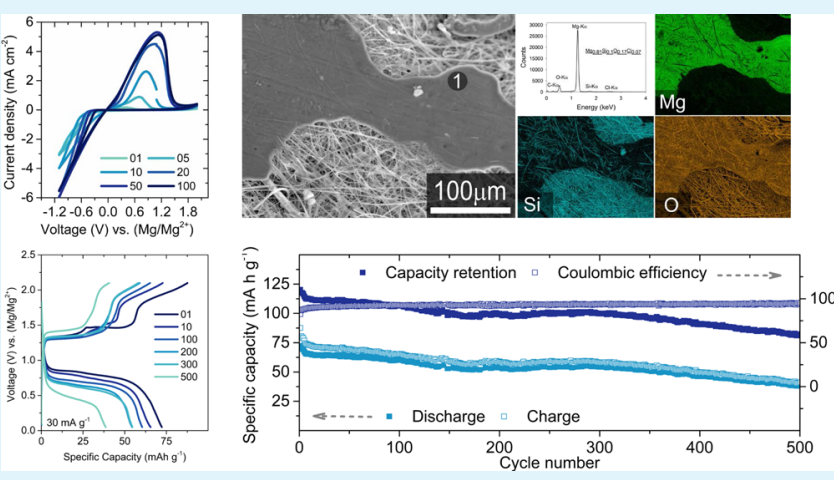
excellent candidate for rechargeable $\mathrm{Mg}$-ion batteries.

KEYWORDS: Mg-ion batteries, electrolytes, ionic liquids, magnesium, energy storage

\section{INTRODUCTION}

The field of Li-ion batteries (LIBs) has shown extraordinary development in the last few decades, ${ }^{1,2}$ which has enabled revolutionary changes in portable electronic devices and now underpins a shift away from fossil-fueled transport. However, to satisfy the demand for more capable and versatile energy storage infrastructure, safer, cheaper, and efficient storage technologies alternative to LIBs are necessary. Rechargeable Mg-ion batteries offer many advantages over $\mathrm{LIBs}^{3-6}$ concerning cost, volumetric capacity, and resistance to dendrite formation that allows the use of metallic $\mathrm{Mg}$ as the anode. ${ }^{7,8}$ Nevertheless, their success toward commercialization is confronted with compelling challenges on the materials front. Lack of suitable electrolytes with favorable ionic conductivity, the ability to efficiently deposit $\mathrm{Mg}^{2+}$ ions reversibly, and a wide electrochemical stability window are some of the most significant challenges to overcome.,

Ethereal solutions of Grignard-based reagents with a wide range of $\mathrm{Mg}$ salts are some of the first known electrolytes for rechargeable $\mathrm{Mg}$-ion batteries with the ability to deposit $\mathrm{Mg}^{2+}$ with high Coulombic efficiency (CE) reversibly. ${ }^{11-13}$ However, these strongly reducing electrolytes have low ionic conductivity, are highly corrosive, and have poor anodic stability $\left(1.0-2.0 \mathrm{~V}\right.$ vs $\left.\left(\mathrm{Mg} / \mathrm{Mg}^{2+}\right)\right)$, restricting them from being used with high voltage cathodes and low-cost collectors. ${ }^{10,13}$ The technical feasibility of rechargeable $\mathrm{Mg}$ batteries is first reported by Gregory et al. methodically with intercalation cathodes using THF solutions of organoborates and organohaloaluminates as the electrolytes. ${ }^{14}$ The CE and anodic stability of the Grignard-type electrolytes are shown to be improved significantly by the addition of aluminum-based Lewis acids $\left(\mathrm{AlCl}_{3}, \mathrm{AlCl}_{2} \mathrm{BuEt}\right.$, etc. $)$ as demonstrated with $\mathrm{Mg}$ organohaloaluminate electrolytes such as the first generation "dichloro complex" (DCC) and the second generation "all phenyl complex" (APC). ${ }^{15,16}$ Nevertheless, the use of strong Lewis acids makes them reactive with sulfur cathodes and raises safety concerns because of their corrosive and combustible nature. ${ }^{12,17}$

Consequently, the hunt for electrolytes with practical applicability for rechargeable $\mathrm{Mg}$ batteries has resulted in a class of electrolytes based on inorganic $\mathrm{Mg}$ salts without Grignard reagents. ${ }^{18-21}$ Non-nucleophilic electrolytes based on magnesium bis(hexamethyldisilazide), $\left[\mathrm{Mg}(\mathrm{HMDS})_{2}\right]^{19,22-24}$ and borate anion-based electrolytes ${ }^{25-27}$ in ethereal solvents have been developed and are shown to have enhanced anodic stability ( $>3.2 \mathrm{~V}$ vs $\mathrm{Mg} / \mathrm{Mg}^{2+}$ ) and $\mathrm{CE}$ as well as excellent compatibility with sulfur cathodes. It is essential to mention

Received: $\quad$ May 4, 2020

Accepted: September 8, 2020

Published: September 8, 2020 
the discovery of reversible $\mathrm{Mg}$ deposition/stripping in a nonhalide electrolyte based on the commercial inorganic salt $\mathrm{Mg}\left(\mathrm{BH}_{4}\right)_{2}$ in both THF and DME. ${ }^{28}$ The low CE and high overpotential for the reversible $\mathrm{Mg}$ deposition process in this electrolyte are found to be improved by involving boron clusters such as magnesium monocarborane (MMC) in tetraglyme. $^{29}$ Recently, electrolytes based on fluorinated alkoxide and dialkoxide are reported to show reversible $\mathrm{Mg}$ deposition/stripping with nearing 100\% CE with high anodic stability ( $>3.0 \mathrm{~V}$ vs $\mathrm{Mg} / \mathrm{Mg}^{2+}$ ) on glassy carbon and gold working electrodes. ${ }^{30,31}$

Most of the magnesium electrolytes contain organometallic magnesium complexes, which are highly hazardous and corrosive. These issues are averted in inorganic electrolyte solutions based on the reaction of $\mathrm{MgCl}_{2}$ and $\mathrm{AlCl}_{3}$ in THF, known as magnesium aluminum chloride complexes (MACC) ${ }^{18,32}$ The cationic species in these electrolytes are THFsolvated $\mathrm{MgCl}^{+}$and $\mathrm{Mg}_{2} \mathrm{Cl}_{3}{ }^{+}$in association with an $\mathrm{AlC}_{4}{ }^{-}$ anion. The MACC electrolytes are reported to exhibit anodic stability of up to $3.4 \mathrm{~V}$ versus $\mathrm{Mg} / \mathrm{Mg}^{2+}$ with $\mathrm{Pt}$ and glassy carbon working electrodes. However, preconditioning of MACC electrolytes is necessary to get the required performance as these electrolytes do not contain any active organometallic components to scavenge reducible contaminants. ${ }^{33,34}$ More extensive discussions on the evolution of electrolytes for rechargeable $\mathrm{Mg}$ batteries can be found in these review papers. ${ }^{35,36}$

Ionic liquids (ILs) exhibit several desirable properties, including wide electrochemical window, high thermal stability, compatibility with a variety of cathode materials, and low vapor pressure. For these reasons, they are extensively investigated as electrolytes for rechargeable Mg-ion batteries. ${ }^{37-41}$ In combination with Grignard reagents, ILs in tetrahydrofuran (THF) are found to support the reversible $\mathrm{Mg}$ deposition/stripping process, but they are not superior compared to other electrolytes discussed earlier in terms of CE. ${ }^{42}$ For instance, a solution of $\mathrm{Mg}\left(\mathrm{BH}_{4}\right)_{2}$ in ammonium-based ILs has shown reversible deposition of $\mathrm{Mg}$ in the presence of an organic solvent dimethoxyethane (DME). ${ }^{43}$ These electrolytes are reductively unstable on $\mathrm{Mg}$ metal anodes, which limit their application in a battery with an $\mathrm{Mg}$ anode. Alkoxy-functionalized ILs are also reported as electrolytes for rechargeable Mgion batteries, but they suffer from low $\mathrm{CE}$ for the reversible $\mathrm{Mg}$ deposition/stripping process. ${ }^{43-45}$

Recently, a magnesium bis(diisopropyl) amide-aluminum chloride $\left(\mathrm{Mg}(\mathrm{DIPA})_{2}-\mathrm{AlCl}_{3}\right)$ electrolyte developed for $\mathrm{Mg}-\mathrm{S}$ batteries is reported to show excellent anodic stability using a stainless steel collector. ${ }^{46}$ There are also reports revealing the potential for chloride-rich electrolytes based on 1-ethyl-3methylimidazolium tetrachloroaluminate $\left(\left[\mathrm{C}_{2} \mathrm{mim}\right]\left[\mathrm{AlCl}_{4}\right]\right)$ and $\mathrm{MgCl}_{2}{ }^{47,48}$ Nevertheless, insertion and extraction of $\mathrm{Mg}$ in a full cell configuration with a proper cathode are not achieved so far with this electrolyte system. Moreover, $\left[\mathrm{C}_{2} \mathrm{mim}\right]\left[\mathrm{AlCl}_{4}\right]$ is either used in either acidic or alkaline electrolytes so far, which are corrosive. ${ }^{4,50}$

In this study, we report a novel electrolyte synthesized by simple mixing of commercially available $\left[\mathrm{C}_{2} \mathrm{mim}\right]\left[\mathrm{AlCl}_{4}\right]$ with non-nucleophilic $\left[\mathrm{Mg}(\mathrm{DIPA})_{2}\right]$ in THF. To the best of our knowledge, this is the first report of a $\mathrm{Mg}(\mathrm{DIPA})_{2}$-based nonnucleophilic $\mathrm{Mg}$ salt in combination with chloroaluminate anion-based ILs as an electrolyte for rechargeable $\mathrm{Mg}$-ion batteries. The neutral species of the chloroaluminate ILs used in this study makes this electrolyte less corrosive for the current collectors at high anodic potentials, which opens up the possibility to work with high-voltage cathodes. ${ }^{49}$

\section{EXPERIMENTAL SECTION}

2.1. Electrolyte Preparation. All the electrolytes are prepared in an argon-filled glove box with oxygen and water contents of less than $0.1 \mathrm{ppm}$. The following chemicals from Sigma-Aldrich are used without any further purification; $\left[\mathrm{Mg}(\mathrm{DIPA})_{2}\right](0.7 \mathrm{M}$ solution in THF), $\left[\mathrm{C}_{2} \mathrm{mim}\right]\left[\mathrm{AlCl}_{4}\right]$ (99.9\%), and THF (anhydrous, 99.9\%). The electrolyte with a 1:2 molar ratio is prepared by adding a solution of 1 $\mathrm{M}\left[\mathrm{Mg}(\mathrm{DIPA})_{2}\right]$ to $2 \mathrm{M}\left(\left[\mathrm{C}_{2} \mathrm{mim}\right]\left[\mathrm{AlCl}_{4}\right]\right)$, which is followed by the addition of anhydrous THF $(2.5 \mathrm{~mL})$ and stirring at ambient conditions for $24 \mathrm{~h}$. The electrolytes with 2:1 and 1:1 molar ratios are prepared through the same procedure.

2.2. Physical and Chemical Characterization of Materials. The electrolytes are characterized by high-resolution mass spectrometry (HRMS) in positive and negative modes using a "Synapt G2-S" Q-TOF instrument equipped with Waters MassLynx software for spectral data processing. No chromatographic separation is used before the mass analysis. Raman measurements are conducted using a Renishaw InVia Reflex microscope with a 785 laser line.

The electrodes and current collectors are characterized by scanning electron microscopy (SEM) using a Hitachi S-3400 N. X-ray diffraction (XRD) patterns are collected using a Bruker D8 Advance A25 equipped with a Mo $\mathrm{K} \alpha$ source and focusing Gøbel mirror, operating in the $\theta-\theta$ configuration. Phases are identified via reference to the ICDD PDF4 +.

2.3. Electrochemical Characterization. Cyclic voltammetry $(\mathrm{CV})$ and linear sweep voltammetry (LSV) are performed using a three-electrode T-cell configuration with graphite foil, stainless steel 316 (SS), and molybdenum as working electrodes. The working electrodes are chosen based on literature reports of their potential application as cathode current collectors. ${ }^{51,52}$ Metallic $\mathrm{Mg}$ discs and $\mathrm{Mg}$ strips were used as counter and reference electrodes, respectively. Both the graphite foil and the metal sheets are of $0.5 \mathrm{~mm}$ thickness, $10 \mathrm{~mm}$ diameter, $>99.9 \%$ in purity, and are procured from Goodfellow. Before cell assembly inside an argon-filled glove box, the metal pieces used are polished using $\mathrm{SiC}$ grinding paper (P800 grit size) and repeatedly washed with dry THF. Cyclic voltammograms are recorded between -1.1 to $2.0 \mathrm{~V}$ versus $\left(\mathrm{Mg} / \mathrm{Mg}^{2+}\right)$ with a scan rate of $50 \mathrm{mV} \mathrm{s}^{-1}$ to determine the $\mathrm{Mg}$ deposition/stripping behavior and CE. Meanwhile, the electrochemical potential window of the electrolyte is measured through LSV from 2.0 to $5.0 \mathrm{~V}$ versus $\left(\mathrm{Mg} / \mathrm{Mg}^{2+}\right)$ with a scan rate of $20 \mathrm{mV} \mathrm{s}^{-1}$ on different working electrodes. Chronoamperometry measurements are carried out by holding the working electrodes at $3.5 \mathrm{~V}$ and $4.5 \mathrm{~V}$ versus $\left(\mathrm{Mg} / \mathrm{Mg}^{2+}\right)$ for 48 hours to deteremine the longterm anodic stability. A VMP3 potentiostat from Biologic Instruments is used to investigate the electrochemical properties of the electrolyte.

The electrochemical performance of the electrolyte in full cell configuration is carried out in CR2016 coin cells. $\mathrm{Mo}_{6} \mathrm{~S}_{8}$, synthesized according to the procedure reported in the literature, is used as the active cathode material. ${ }^{53}$ The cathode slurry is initially formed by milling $\mathrm{Mo}_{6} \mathrm{~S}_{8}$ with Ketjenblack EC300J carbon and polyvinylidene fluoride (PVDF) in 80:10:10 weight ratio, with $N$-methyl-2pyrrolidone (NMP) and acetone (1:10 weight ratio) as solvents. Circular cathodes of $16 \mathrm{~mm}$ diameter are prepared on both molybdenum and graphite foil current collectors by drop coating the slurry onto the respective substrates. The coated substrates are dried overnight at $120^{\circ} \mathrm{C}$ under vacuum to obtain an active material loading of approximately $2 \mathrm{mg} \mathrm{cm}^{-2}$. The coin cells are assembled inside an argon-filled glove box with polished $\mathrm{Mg}$ metal as the anode and a glass microfiber (Whatman GF/D) separator. Galvanostatic discharge/charge cycling is performed using a BCS- 805 battery cycler from Biologic Instruments.

\section{RESULTS AND DISCUSSION}

The electrochemical performance of electrolytes could be tailored by varying the ratios of the ILs and the concentrations 
of $\mathrm{Mg}$ salt in the ILs. The cyclic voltammograms of $\mathrm{Mg}$ deposition/stripping behavior of the $\left[\mathrm{Mg}(\mathrm{DIPA})_{2}\right]$ and $\left(\left[\mathrm{C}_{2} \mathrm{mim}\right]\left[\mathrm{AlCl}_{4}\right]\right)$ electrolyte in three different molar ratios; $2: 1,1: 1$, and 1:2, respectively are shown in Figure 1a.
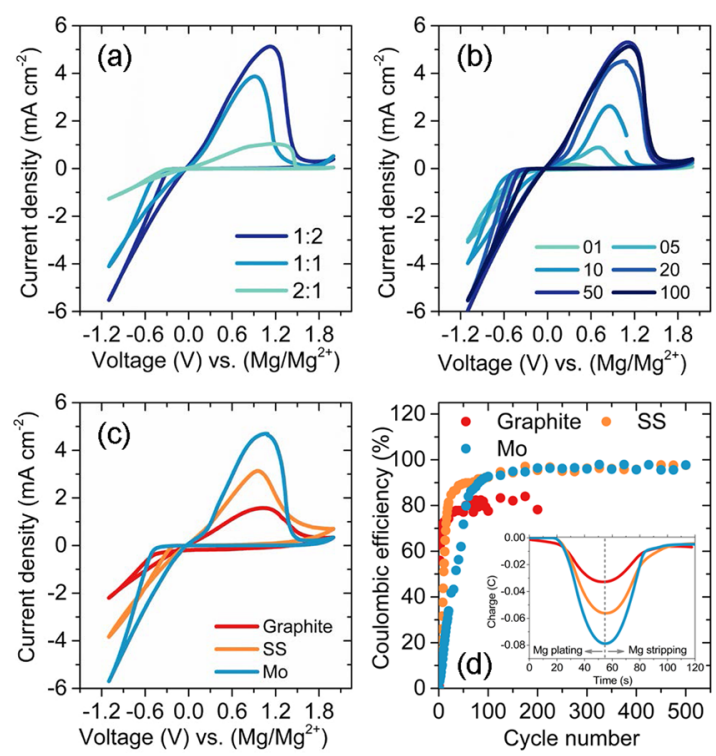

Figure 1. (a) CVs showing $\mathrm{Mg}$ deposition/stripping in the IL-based electrolyte with different ratios of $\mathrm{Mg}\left[(\mathrm{DIPA})_{2}\right]-\left[\mathrm{C}_{2} \mathrm{mim}\right]\left[\mathrm{AlCl}_{4}\right]$ using a Mo working electrode recorded at a scan rate of $50 \mathrm{mV} \mathrm{s}^{-1}$. (b) CVs showing the reversibility of the $\mathrm{Mg}$ deposition/stripping process for 100 cycles in the $1: 2 \mathrm{Mg}\left[(\mathrm{DIPA})_{2}\right]-\left[\mathrm{C}_{2} \mathrm{mim}\right]\left[\mathrm{AlCl}_{4}\right]$ electrolyte using a Mo working electrode recorded at a scan rate of 50 $\mathrm{mV} \mathrm{s}^{-1}$. (c) CVs showing $\mathrm{Mg}$ deposition/stripping in the $1: 2$ $\operatorname{Mg}\left[(\mathrm{DIPA})_{2}\right]-\left[\mathrm{C}_{2} \mathrm{mim}\right]\left[\mathrm{AlCl}_{4}\right]$ electrolyte using different working electrodes recorded at a scan rate of $50 \mathrm{mV} \mathrm{s}^{-1}$. (d) Coulombic efficiencies of the extended reversible $\mathrm{Mg}$ deposition/stripping process with different working electrodes evaluated from CVs using the $1: 2 \mathrm{Mg}\left[(\mathrm{DIPA})_{2}\right]-\left[\mathrm{C}_{2} \mathrm{mim}\right]\left[\mathrm{AlCl}_{4}\right]$ electrolyte, and the inset shows the plot of charge over time from the 100th CV scan

Reversible $\mathrm{Mg}$ deposition/stripping is achieved on a Mo substrate with all the three electrolyte compositions. The observed $\mathrm{CV}$ profiles are typical for $\mathrm{Mg}$ dissolution and electrodeposition, with the oxidation current between 0 and $1.6 \mathrm{~V}$ versus $\left(\mathrm{Mg} / \mathrm{Mg}^{2+}\right)$ representing $\mathrm{Mg}$ dissolution and the reduction current between 0 and $-1.1 \mathrm{~V}$ versus $\left(\mathrm{Mg} / \mathrm{Mg}^{2+}\right)$ corresponding to $\mathrm{Mg}$ electrodeposition. The overpotential and the CE are, however, found to vary with the relative concentrations of the dissolved complexes in THF, with the 1:2 ratio between $\mathrm{Mg}\left[(\mathrm{DIPA})_{2}\right]-\left[\mathrm{C}_{2} \mathrm{mim}\right]\left[\mathrm{AlCl}_{4}\right]$ being the most efficient.

The mechanism for the formation of the electrolyte with a $1: 2$ ratio of $\mathrm{Mg}\left[(\mathrm{DIPA})_{2}\right]-\left[\mathrm{C}_{2} \mathrm{mim}\right]\left[\mathrm{AlCl}_{4}\right]$ is proposed in Scheme 1. Initially, upon mixing, two types of positively and negatively charged ions are formed in the electrolyte. It has been reported that bis(amide)-based $\mathrm{Mg}$ salt, in combination with Lewis acids such as $\mathrm{AlCl}_{3}$, tend to form a positively charged ion (3) and negatively charged ion (5). ${ }^{50}$ ESI-MS analysis in the negative ion mode shows a strong peak at $\mathrm{m} / z=$ 233.5231 (Figure S1), which corresponds to the presence of aluminum species (5) in the electrolyte. Similarly, the existence of the $\left[\mathrm{C}_{2} \mathrm{mim}\right]$ cation in the electrolyte is concluded by the presence of molecular ion peak at $m / z=111.0918$ (Figure S2) when investigated in the positive ion mode. However, no signals for the chloride anion are observed, which could be due
Scheme 1. Preparation of the Electrolyte Based on $\left[\mathrm{Mg}(\mathrm{DIPA})_{2}\right]-\left[\mathrm{C}_{2} \mathrm{mim}\right]\left[\mathrm{AlCl}_{4}\right]$. (1) Magnesium bis(diisopropyl)amide, (2) 1-Ethyl-3-methylimidazolium Tetrachloroaluminate, (3) $\left[(\mu-\mathrm{Cl})_{3} \mathrm{Mg}_{2}(\mathrm{THF})_{6}\right]^{+}$Dimer, (4) Chloride Anion, (5) Trichloro-isopropyl Amide Aluminate Complex, (6) 1-Ethyl-3-methylimidazolium Cation

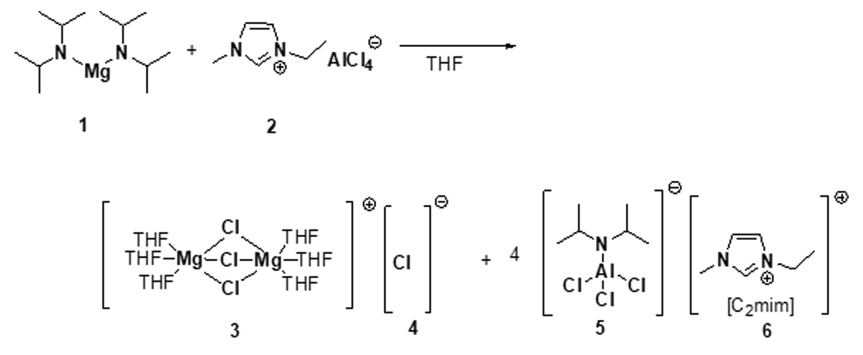

to their low molecular mass, making it undetectable in the mass spectrometer. The molecular ion peak corresponds to the $\mathrm{Mg}$ complex, $\left[\mathrm{Mg}_{2}(\mu-\mathrm{Cl})_{3}(\mathrm{THF})_{6}\right]^{+}$, which is also not observed in the ESI-MS analysis. The interaction between $\mathrm{Mg}$ and THF is very weak, and it would not survive the harsh operating conditions of ESI-MS with an inlet temperature of more than $200{ }^{\circ} \mathrm{C} .{ }^{54}$ Nevertheless, there is no conclusive evidence for the association of the ions in the order, as shown in Scheme 1.

Raman spectroscopic studies performed on the electrolyte to identify $\left[\mathrm{Mg}_{2}(\mu-\mathrm{Cl})_{3}(\mathrm{THF})_{6}\right]^{+}$yielded an unresolved spectrum initially due to strong fluorescence interferences from the solvent molecules, which is in accordance with the earlier reported studies. ${ }^{54}$ However, the spectra (Figure S3) obtained from the solidified electrolyte after removing the THF solvent that shows a characteristic peak at around $242 \mathrm{~cm}^{-1}$ corresponds to $\mathrm{MgCl}_{3}^{+}$in the $\left[\mathrm{Mg}_{2}(\mu-\mathrm{Cl})_{3}(\mathrm{THF})_{6}\right]^{+}$complex. ${ }^{33,55}$ Besides, the characteristic peak of $\mathrm{AlCl}_{4}{ }^{-}$is observed at $311 \mathrm{~cm}^{-1}$. However, the peak for its dimer $\mathrm{Al}_{2} \mathrm{Cl}_{7}^{-}(347$ $\left.\mathrm{cm}^{-1}\right)$ is not observed in the electrolyte. ${ }^{56}$ The bands observed at around 1087, 847, and $739 \mathrm{~cm}^{-1}$ belong to the ring asymmetric bending/stretching vibrations in the $\left[\mathrm{C}_{4} \mathrm{mim}\right]$ ring from the ionic liquids. ${ }^{57}$

The evolution of the $\mathrm{Mg}$ deposition/stripping process on the Mo working electrode using the electrolyte with a $1: 2$ ratio is shown in Figure $1 \mathrm{~b}$. The performance of the electrolyte concerning the $\mathrm{CE}$, overpotential, and current density for the $\mathrm{Mg}$ stripping/deposition process improves significantly with the cycle number. For instance, the overpotential, which is the difference between the onset potentials of $\mathrm{Mg}$ electroplating and stripping on the Mo working electrode improved significantly from $375 \mathrm{mV}$ in the first cycle to $225 \mathrm{mV}$ at the 100th cycle. The overpotential derived from the CVs at $0.2 \mathrm{~mA}$ $\mathrm{cm}^{-2}$ for the $\mathrm{Mg}$ stripping/deposition process on the Mo working electrode remained stable for at least $500 \mathrm{CV}$ cycles, as shown in Figure S4. A similar trend in the overpotential is also found on the graphite and SS working electrodes (Figure S5).

The reversibility for the $\mathrm{Mg}$ stripping/deposition process (Figure 1c) and the evolution of the CE over extended cycling (Figure 1d) in the IL-based electrolyte with a $1: 2$ ratio is investigated through CVs using graphite foil, SS, and Mo working electrodes. Figure $1 \mathrm{c}$ demonstrates good reversibility for the $\mathrm{Mg}$ stripping/deposition process in all the three working electrodes in general. The CEs on different working electrodes are obtained from the plots of charge over time, as 

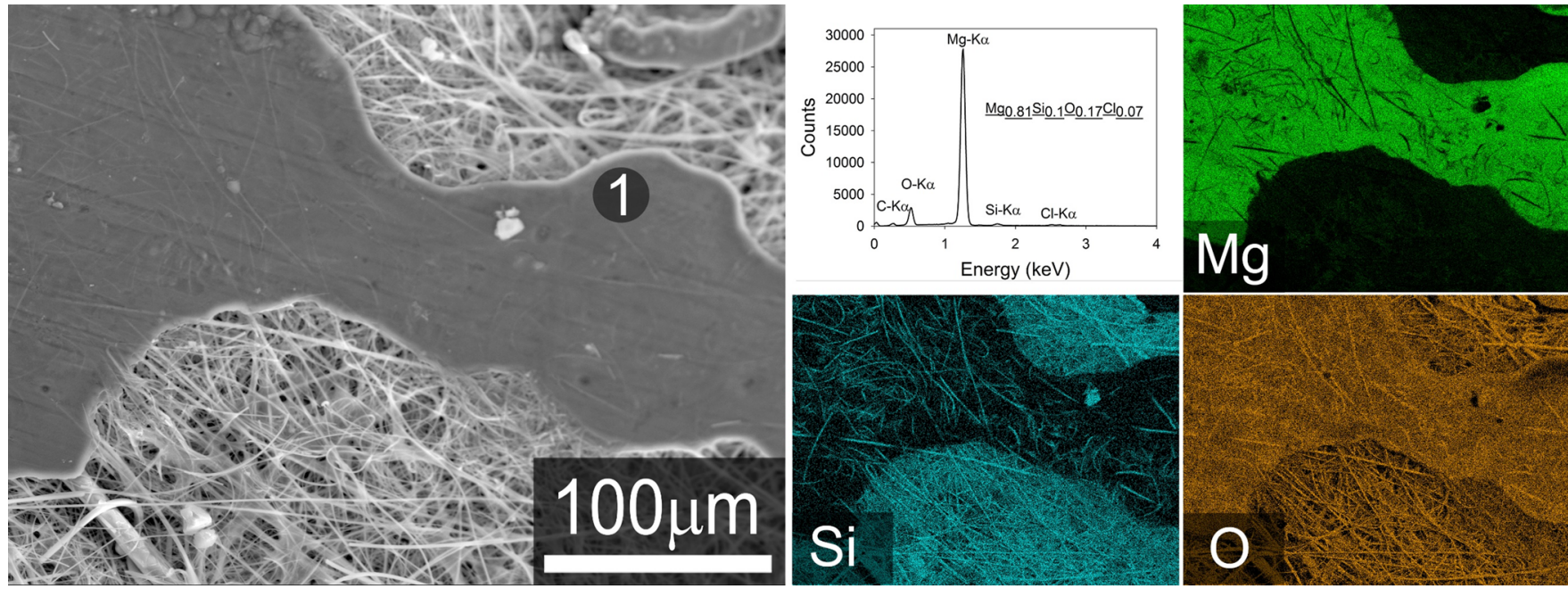

Figure 2. SEM image with associated EDS maps of the electrodeposited $\mathrm{Mg}$ on a Mo working electrode in the $1: 2 \mathrm{Mg}\left[(\mathrm{DIPA})_{2}\right]-\left[\mathrm{C}_{2} \mathrm{mim}_{[}\left[\mathrm{AlCl}_{4}\right]\right.$. ( $\mathrm{Mg}$ electrodeposits shown in the image are attached to the glass fiber separator during disassembly of the cell.)

shown in the inset of Figure 1d. While a significantly low CE is observed for all the working electrodes during the first cycles, the CE drastically improved with each cycle, ultimately reaching values of 78,92 , and $92 \%$, respectively for the graphite foil, SS, and Mo at the 100th cycle. The CE of the Mo and SS working electrodes stabilizes in the range of $95-98 \%$ at the end of 500 cycles, suggesting decomposition of some of the electrolyte components and impurities accompanying the $\mathrm{Mg}^{2+}$ reduction for the nonunity $C E$. Such improvement in the overpotential and $\mathrm{CE}$ during reversible electrochemical cycling is a known phenomenon in electrolytes containing magnesium aluminum chloride, magnesium bis(trifluoromethylsulfonyl)imide, and $\mathrm{Mg}(\mathrm{TFSI})_{2}$-glyme complexes and is related to the removal of water during cycling. ${ }^{33,58}$ Besides, a significantly lower $\mathrm{CE}$ for the graphite foil is not understood. The complexity involving the interactions between the graphite electrode surface and the electrolyte and the critical role played by even a trace amount of water impurity $(<3 \mathrm{ppm})$ on altering the double-layer structure could play a significant role in determining $\mathrm{Mg}$ reversibility. ${ }^{59,60}$ Mo exhibits the highest $\mathrm{Mg}$ deposition and stripping current density compared to graphite foil and SS. SEM-EDS and XRD results (Figure 2 and Figure S6, respectively) confirm the deposition of metallic $\mathrm{Mg}$ electrodeposited on a Mo working electrode at a current density of $0.5 \mathrm{~mA} \mathrm{~cm}^{-2}$ for $1 \mathrm{~h}$.

Figure 3a shows the oxidative stability of the electrolyte using different working electrodes examined through LSV in the potential range of $2.0-5.0 \mathrm{~V}$ versus $\left(\mathrm{Mg} / \mathrm{Mg}^{2+}\right)$. For comparison, LSV measurements are also carried out using a $\mathrm{Pt}$ working electrode under the same conditions. No marked increase in the current up to about $3.0 \mathrm{~V}$ manifests that the electrolyte, in general, has high intrinsic anodic stability and excellent compatibility with different working electrodes. The onset of the electro-oxidation process is advanced for the graphite foil and $\mathrm{Pt}$ with the anodic current beginning to surge as early as $3.0 \mathrm{~V}$, which could be due to the catalytic reactions on the surface of these electrodes that oxidize trace impurities including water from the electrolyte. Similarly, a small increase in the oxidation current is observed on the SS and Mo electrodes at about $3.0 \mathrm{~V}$, suggesting the formation of a passivation layer on the SS and Mo electrode surface. However, the steep rise in the anodic current is significantly
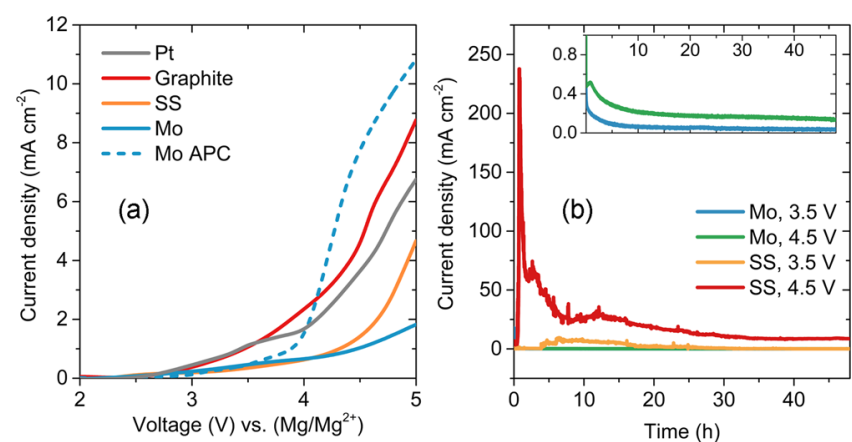

Figure 3. (a) Anodic LSVs using the $1: 2 \mathrm{Mg}\left[(\mathrm{DIPA})_{2}\right]-\left[\mathrm{C}_{2} \mathrm{mim}\right]-$ $\left[\mathrm{AlCl}_{4}\right]$ electrolyte with different working electrodes recorded at a 20 $\mathrm{mV} \mathrm{s}^{-1}$ scan rate (LSV of the state-of-the-art APC electrolyte with a Mo working electrode is included for comparison). (b) Chronoamperometry measurements for the Mo and SS working electrodes using $1: 2 \mathrm{Mg}\left[(\mathrm{DIPA})_{2}\right]-\left[\mathrm{C}_{2} \mathrm{mim}\right]\left[\mathrm{AlCl}_{4}\right]$ electrolyte at 3.5 and $4.5 \mathrm{~V}$ vs $\left(\mathrm{Mg} / \mathrm{Mg}^{2+}\right)$

delayed on these working electrodes. No appreciable increase in the oxidation current corresponding to the electrolyte or electrode degradation is noticed up to $4.3 \mathrm{~V}$ for both SS and Mo. Importantly, for Mo, the increase in the anodic current is considerably suppressed even up to $5.0 \mathrm{~V}$. In comparison, the anodic stability of the state-of-the-art all phenyl complex (APC) electrolyte measured using the Mo working electrode is inferior, and the degradation starts at $3.6 \mathrm{~V}$.

Chronoamperometry measurements carried out at potentials of $3.5 \mathrm{~V}$ and $4.5 \mathrm{~V}$ versus $\left(\mathrm{Mg} / \mathrm{Mg}^{2+}\right)$ for $48 \mathrm{~h}$ to study the oxidation stability of the electrolyte with SS and Mo working electrodes are shown in Figure 3b. Although a mild but notable evolution of oxidation currents is observed for the SS working electrode while holding at $3.5 \mathrm{~V}$, large oxidation currents are eventually obtained at $4.5 \mathrm{~V}$. SEM micrographs (Figure $4 \mathrm{a}-\mathrm{c}$ ) of SS current collectors before and after stability testing at 3.5 $\mathrm{V}$ are shown, and $4.5 \mathrm{~V}$ provides clear evidence of corrosion, with high levels of pitting evident. Under testing at $3.5 \mathrm{~V}$, the tested SS initially appears stable, thus complementing the results from LSV measurements shown in Figure 3 a.

Nevertheless, an increase in the oxidation current is observed to occur after around $4 \mathrm{~h}$, suggesting that the corrosion of SS occurs over time. Interestingly, the high 


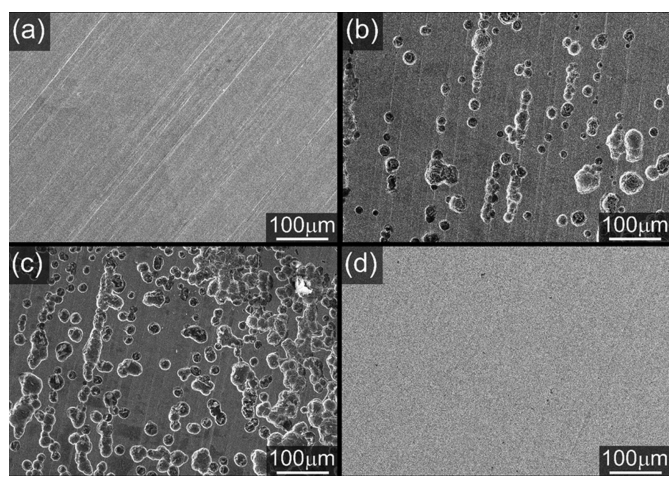

Figure 4. Secondary electron micrographs of SS316 (a) polished, (b) after $48 \mathrm{~h}$ hold at $3.5 \mathrm{~V}$, (c) after $48 \mathrm{~h}$ hold at $4.5 \mathrm{~V}$. Molybdenum after $48 \mathrm{~h}$ hold at $4.5 \mathrm{~V}$ is given in (d)

magnification image of the corrosion (Figure S7) shows morphology more consistent with grain boundary (intergranular) corrosion than with bulk corrosion, which may suggest a route to stable SS substrates via control of grain boundary composition. Nevertheless, comparison with the literature suggests that the SS tested here appears more stable to corrosion with the IL-based electrolyte reported in this work than a similar material tested with APC and (HMDS) ${ }_{2} \mathrm{Mg}$ $\mathrm{AlCl}_{3} /$ tetraglyme. ${ }^{61}$

In contrast, the oxidation currents from the Mo working electrodes are very low at both the potentials due to the formation of stable passivation layers on the Mo substrate. SEM micrographs taken after the potential hold test at $4.5 \mathrm{~V}$ confirm this, with no detectable corrosion being observed (Figure 4d). These results correlate well with the report that Mo develops stable passive films in chloride-containing electrolytes such as APC. ${ }^{62}$ The non-nucleophilic nature of the ILs employed in this work is considered to provide a less corrosive environment to Mo and SS current collectors, thus significantly enhancing their anodic stability.

Figure 5a shows the performance of the $1: 2 \mathrm{Mg}\left[(\mathrm{DIPA})_{2}\right]$ $\left[\mathrm{C}_{2} \mathrm{mim}\right]\left[\mathrm{AlCl}_{4}\right]$ electrolyte for reversible $\mathrm{Mg}$ intercalation and extraction investigated by $\mathrm{CV}$ analysis with a Chevrel phase $\mathrm{Mo}_{6} \mathrm{~S}_{8}$ cathode on a Mo current collector. The CV profiles indicate that the electrolyte facilitates the $\mathrm{Mg}$ intercalation/ extraction process with a high level of reversibility for at least $100 \mathrm{CV}$ cycles. As reported in the literature, a two-step $\mathrm{Mg}$ intercalation process in $\mathrm{Mo}_{6} \mathrm{~S}_{8}$ is observed, indicating the sequential formation of $\mathrm{MgMo}_{6} \mathrm{~S}_{8}$ and $\mathrm{Mg}_{2} \mathrm{Mo}_{6} \mathrm{~S}_{8}$ (Figure 5a, inset). ${ }^{63,64}$ However, as observed from the figure, distinguishing between the two cathodic peaks is not straightforward due to overlap.

The full cell performance of the electrolyte is investigated galvanostatically at 15 and $30 \mathrm{~mA} \mathrm{~g}^{-1}$ with a $\mathrm{Mo}_{6} \mathrm{~S}_{8}$ cathode on a graphite foil and Mo current collector. According to Figure $5 \mathrm{~b}, \mathrm{Mo}_{6} \mathrm{~S}_{8}$ exhibits better rate capability with a Mo current collector than with a graphite foil. Since the electrode materials and the electrolyte are the same in both the measurements, the electrochemical processes at the electrode/electrolyte interface are assumed to be identical. Therefore, the difference in the rate performance could have resulted from the inherent properties of the current collector and the nature of the cathode/current collector interface. Being metal, the electrical conductivity of Mo $\left(1.9 \times 10^{7} \mathrm{~S} \mathrm{~m}^{-1}\right)$ is significantly higher than graphite $\left(3.3 \times 10^{2}-2.5 \times 10^{5} \mathrm{~S} \mathrm{~m}^{-1}\right)$. Also, the interfacial resistance resulting from the surface oxides on the current collectors, wettability, and poor adhesion of the active layer could affect the cell performance at high C-rates.
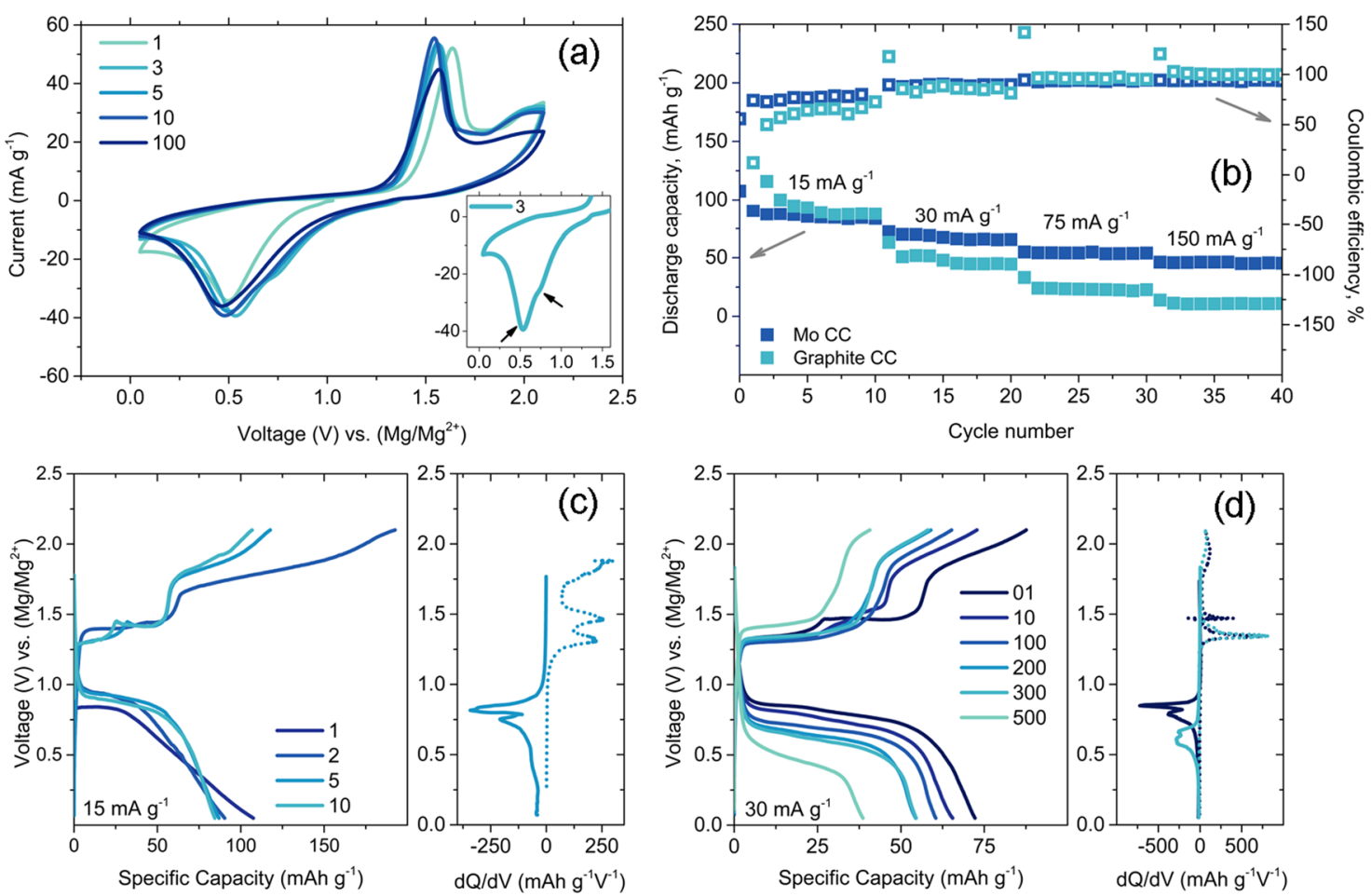

Figure 5. (a) CV curves of Mg-ion full cell with $\mathrm{Mo}_{6} \mathrm{~S}_{8}$ cathode in $1: 2 \mathrm{Mg}\left[(\mathrm{DIPA})_{2}\right]-\left[\mathrm{C}_{2} \mathrm{mim}\right]\left[\mathrm{AlCl}_{4}\right]$ electrolyte at a scan rate of $0.2 \mathrm{mV} \mathrm{s} \mathrm{s}^{-1}$. (b) Rate performance with a $\mathrm{Mo}_{6} \mathrm{~S}_{8}$ cathode in $1: 2 \mathrm{Mg}\left[(\mathrm{DIPA})_{2}\right]-\left[\mathrm{C}_{2} \mathrm{mim}\right]\left[\mathrm{AlCl}_{4}\right]$ electrolyte (c) Galvanostatic charge-discharge performance at 15 $\mathrm{mA} \mathrm{g}^{-1}$ and the associated $\mathrm{d} Q / \mathrm{d} V$ curves. (d) Long-term cycling performance at $30 \mathrm{~mA} \mathrm{~g}^{-1}$ and the associated $\mathrm{dQ} / \mathrm{d} V$ curves 

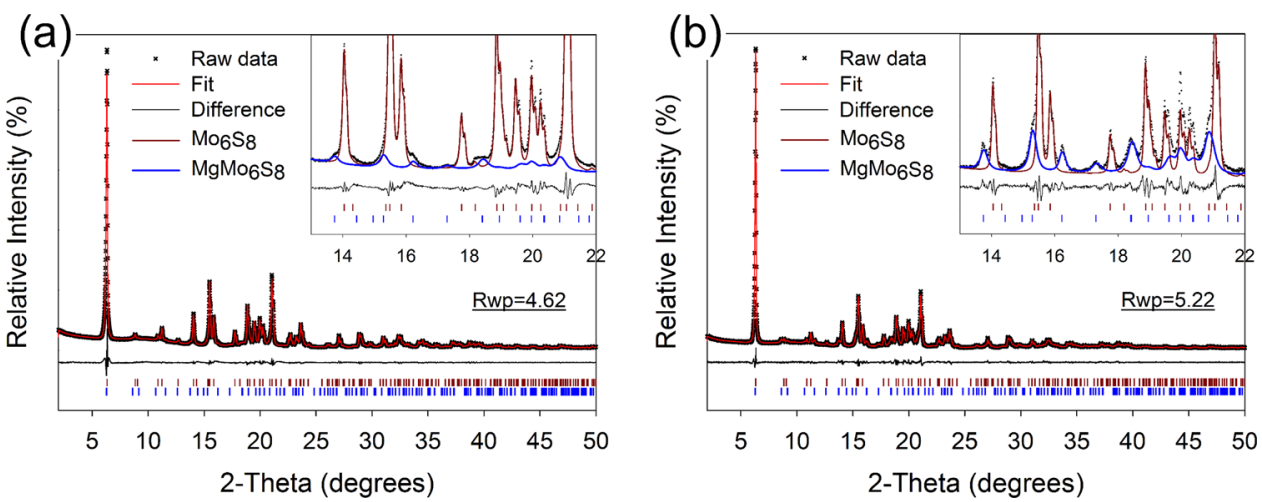

Figure 6. XRD patterns of the $\mathrm{Mo}_{6} \mathrm{~S}_{8}$ cathode measured (a) after the first discharge cycle and (b) after the first charge cycle

Figure 5c shows selected charge/discharge profiles of the $\mathrm{Mg}$-ion cell from the first 10 cycles at $15 \mathrm{~mA} \mathrm{~g}^{-1}$. The plateau potential of the first discharge is found to be slightly lower than for the subsequent cycles, suggesting improved kinetics after the first cycle. At the end of the first discharge, a specific capacity of $110 \mathrm{~mA} \mathrm{~g}^{-1}$ is achieved against the theoretical value of $128 \mathrm{~mA} \mathrm{~g}^{-1}$ for the $\mathrm{Mo}_{6} \mathrm{~S}_{8}$ cathode. After the first discharge/ charge cycle, the cell performance is found to be stable, and at the end of 10 cycles, the cathode is able to provide a specific capacity of $85 \mathrm{~mA} \mathrm{~g}^{-1}$, which is consistent with the values reported in the literature under similar currents. ${ }^{50,65}$

Structural analysis of the $\mathrm{Mo}_{6} \mathrm{~S}_{8}$ cathode is performed after the first discharge and after the first charge step, using XRD to understand the reversibility of the $\mathrm{Mg}$ intercalation/extraction process during cycling (Figure $6 \mathrm{a}, \mathrm{b}$ ). The XRD pattern of the $\mathrm{Mo}_{6} \mathrm{~S}_{8}$ cathode after $\mathrm{Mg}^{2+}$ insertion during the first discharge process exhibits two phases, the host $\mathrm{Mo}_{6} \mathrm{~S}_{8}$ phase and a newly formed $\mathrm{MgMo}_{6} \mathrm{~S}_{8}$ phase. $\mathrm{Mg}^{2+}$ intercalation (and extraction) into $\mathrm{Mo}_{6} \mathrm{~S}_{8}$ occurs in two stages, and the differential capacity $(\mathrm{d} Q / \mathrm{d} V)$ plotted as a function of voltage (Figure $5 \mathrm{c}$ ) confirms the presence of two magnesiation and two demagnesiation processes occurring in the $\mathrm{Mo}_{6} \mathrm{~S}_{8}$ cathode. However, it is essential to note that the $\mathrm{XRD}$ analysis does not verify the second $\mathrm{Mg}_{2} \mathrm{Mo}_{6} \mathrm{~S}_{8}$ phase. $\mathrm{Mg}_{2} \mathrm{Mo}_{6} \mathrm{~S}_{8}$ phase is generally considered to be unstable when exposed to air. ${ }^{66,67}$ Once exposed (in this case for XRD analysis), $\mathrm{Mg}_{2} \mathrm{Mo}_{6} \mathrm{~S}_{8}$ would react with oxygen steadily, resulting in the extraction of $\mathrm{Mg}^{2+}$ from this phase, and this could be the reason that this phase is not observed in the XRD studies.

The XRD pattern of the $\mathrm{Mo}_{6} \mathrm{~S}_{8}$ cathode after a fully charged state shows that $\mathrm{Mo}_{6} \mathrm{~S}_{8}$ is the dominant phase, and it is an indication that the $\mathrm{Mg}^{2+}$ insertion/extraction process is reversible. However, the figure shows that complete reversibility is not achieved, and a trace amount of $\mathrm{MgMo}_{6} \mathrm{~S}_{8}$ is still observed after the extraction process. This behavior of partial $\mathrm{Mg}^{2+}$ trapping in the host $\mathrm{Mo}_{6} \mathrm{~S}_{8}$ during extraction at room temperature is reported in detail in the literature. ${ }^{67}$ This partial entrapment of $\mathrm{Mg}^{2+}$ during the first charge step results in the drop in cell capacity, in this work from 110 to $90 \mathrm{mAh} \mathrm{g}^{-1}$. The inability to completely extract $\mathrm{Mg}^{2+}$ is a drawback, as this cathode cannot be fully utilized, resulting in a lower practical, specific energy.

The cyclic stability and the associated charge/discharge curves of the $\mathrm{Mg}$-ion cell cycled at a current rate of $30 \mathrm{~mA} \mathrm{~g}^{-1}$ shown in Figures 5d and 7, indicate that the IL-based electrolyte can support the reversible electrochemical processes over a long period. According to the figures, a noticeable drop

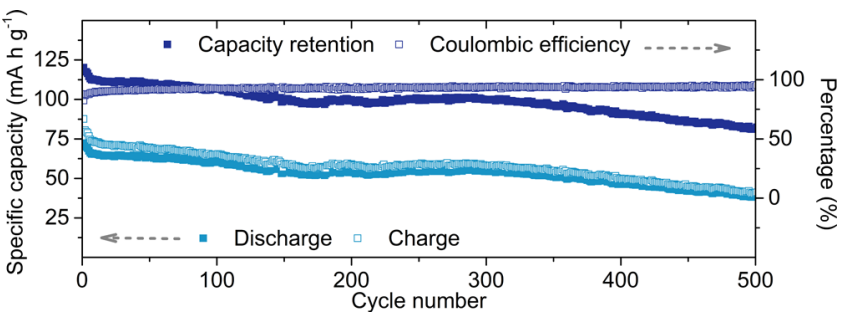

Figure 7. Cyclic stability, capacity retention, and Coulombic efficiency of Mg-ion full cell charged and discharged at $30 \mathrm{~mA} \mathrm{~g}^{-1}$ with the $\mathrm{Mo}_{6} \mathrm{~S}_{8}$ cathode in the $1: 2 \mathrm{Mg}\left[(\mathrm{DIPA})_{2}\right]-\left[\mathrm{C}_{2} \mathrm{mim}\right]\left[\mathrm{AlCl}_{4}\right]$ electrolyte

in the discharge performance (from 74 to $68 \mathrm{mAh} \mathrm{g}^{-1}$ ) is observed during the first 10 cycles. After the initial performance loss, the cell is able to perform for hundreds of cycles with a nominal loss in capacity and with a CE of $93 \%$. Above all, if normalized with the discharge capacity obtained at the end of the formation cycles (first 10 cycles), the cell is found to cycle for about 335 cycles with less than $20 \%$ loss in the initial capacity.

To demonstrate the applicability of the proposed electrolyte with high voltage cathodes, full cell cycling tests are conducted using $\mathrm{V}_{2} \mathrm{O}_{5}$ as the cathode material, and the results are collected in Figure S8. Besides, the charge/discharge profile of the $\mathrm{V}_{2} \mathrm{O}_{5}$ cathode cycled with the APC electrolyte is included in the figure for comparison. A significant improvement in the charge/discharge performance is observed with the $\mathrm{V}_{2} \mathrm{O}_{5}$ cathode when using the $1: 2 \mathrm{Mg}\left[(\mathrm{DIPA})_{2}\right]$ and $\left[\mathrm{C}_{2} \mathrm{mim}\right]$ $\left[\mathrm{AlCl}_{4}\right]$ electrolyte, validating the suitability of the IL-based electrolyte with high-voltage cathode materials. Notably, the charging voltage could be pushed to $>3.5 \mathrm{~V}$ with the IL-based electrolyte enabled by the electrolyte's superior anodic stability. A specific capacity of about $70 \mathrm{mAh} \mathrm{g}^{-1}$ is obtained from the first discharge, which is similar to what is reported in the literature. ${ }^{68}$ On the downside, the cathode material exhibited a short cycle life, and understanding the failure mechanisms is a subject for further research. In short, the half cell and full cell results obtained in this work demonstrate that by providing high anodic stability and cycle life, the new ILbased electrolyte reported here would be an excellent candidate for high-voltage rechargeable $\mathrm{Mg}$-ion batteries.

\section{CONCLUSIONS}

In this work, we have developed a novel non-nucleophilic ILbased electrolyte containing $\mathrm{Mg}\left[(\mathrm{DIPA})_{2}\right]$ and $\left[\mathrm{C}_{2} \mathrm{mim}\right]$ $\left[\mathrm{AlCl}_{4}\right]$ in 1:2 molar ratio for rechargeable $\mathrm{Mg}$-ion batteries. 
The electrolyte shows superior performance in terms of reversibility and $\mathrm{CE}$ for the $\mathrm{Mg}$ deposition/stripping process. In combination with Mo as the working electrode (cathode current collector), the electrolyte is found to be electrochemically stable up to at least $4.5 \mathrm{~V}$, and no corrosion of Mo is found even after holding it at $4.5 \mathrm{~V}$ for $48 \mathrm{~h}$. A lifetime of over 300 cycles with $>80 \%$ capacity retention is achieved in the full cell test with a $\mathrm{Mo}_{6} \mathrm{~S}_{8}$ cathode. Besides, as the proof of concept, the electrolyte is also proven to work with a high-voltage $\mathrm{V}_{2} \mathrm{O}_{5}$ cathode. The straight forward, easy, and scalable synthesis method of the new electrolyte in combination with its excellent half-cell properties and full cell performance with prototype $\mathrm{Mo}_{6} \mathrm{~S}_{8}$ and $\mathrm{V}_{2} \mathrm{O}_{5}$ cathodes make this electrolyte an excellent candidate for rechargeable $\mathrm{Mg}$ batteries.

\section{ASSOCIATED CONTENT}

\section{SI Supporting Information}

The Supporting Information is available free of charge at https://pubs.acs.org/doi/10.1021/acsaem.0c01026.

ESI-MS and Raman spectra of the electrolyte, electrochemical performance of the electrolyte in half-cells, XRD of the electrodeposited Mg, SEM of the corroded SS working electrode, charge/discharge cycles of the $\mathrm{Mg} / \mathrm{V}_{2} \mathrm{O}_{5}$ full cell, and XRD and SEM of $\mathrm{V}_{2} \mathrm{O}_{5}$ (PDF)

\section{AUTHOR INFORMATION}

\section{Corresponding Authors}

Lethesh Kallidanthiyil Chellappan - Department of Chemistry, Norwegian University of Science and Technology (NTNU), Trondheim 7491, Norway;

Email: lethesh.k.chellappan@ntnu.no

Kaushik Jayasayee - New Energy Solutions, SINTEF Industry, Trondheim 7034, Norway; 이이이.org/0000-0001-55325636; Email: kaushik.jayasayee@sintef.no

\section{Authors}

Jannicke Kvello - New Energy Solutions, SINTEF Industry, Trondheim 7034, Norway

Julian Richard Tolchard - New Energy Solutions, SINTEF Industry, Trondheim 7034, Norway

Paul Inge Dahl - New Energy Solutions, SINTEF Industry, Trondheim 7034, Norway

Sidsel Meli Hanetho - New Energy Solutions, SINTEF Industry, Trondheim 7034, Norway

Romain Berthelot - ICGM, University of Montpellier, CNRS, Montpellier 34090, France; Réseau sur le Stockage Electrochimique de l'Energie (RS2E), CNRS, Amiens 80039, France

Anne Fiksdahl - Department of Chemistry, Norwegian University of Science and Technology (NTNU), Trondheim 7491, Norway

Complete contact information is available at: https://pubs.acs.org/10.1021/acsaem.0c01026

\section{Notes}

The authors declare no competing financial interest.

\section{ACKNOWLEDGMENTS}

The authors acknowledge financial support from the Research Council of Norway through ADMIRE (255108) under the ENERGIX program.

\section{REFERENCES}

(1) Goodenough, J. B.; Park, K.-S. The Li-ion rechargeable battery: a perspective. J. Am. Chem. Soc. 2013, 135, 1167-1176.

(2) Hassoun, J.; Lee, K.-S.; Sun, Y.-K.; Scrosati, B. An advanced lithium ion battery based on high performance electrode materials. $J$. Am. Chem. Soc. 2011, 133, 3139-3143.

(3) Pan, B.; Zhang, J.; Huang, J.; Vaughey, J. T.; Zhang, L.; Han, S.D.; Burrell, A. K.; Zhang, Z.; Liao, C. A Lewis acid-free and phenolate-based magnesium electrolyte for rechargeable magnesium batteries. Chem. Commun. 2015, 51, 6214-6217.

(4) Liao, C.; Sa, N.; Key, B.; Burrell, A. K.; Cheng, L.; Curtiss, L. A.; Vaughey, J. T.; Woo, J.-J.; Hu, L.; Pan, B.; Zhang, Z. The unexpected discovery of the $\mathrm{Mg}$ (HMDS) $2 / \mathrm{MgCl} 2$ complex as a magnesium electrolyte for rechargeable magnesium batteries. J. Mater. Chem. A 2015, 3, 6082-6087.

(5) Yoshio, M.; Brodd, R. J.; Kozawa, A. Lithium-ion batteries; Springer: 2009; Vol. 1.

(6) Jaguemont, J.; Boulon, L.; Dubé, Y. A comprehensive review of lithium-ion batteries used in hybrid and electric vehicles at cold temperatures. Appl. Energy 2016, 164, 99-114.

(7) Yoo, H. D.; Shterenberg, I.; Gofer, Y.; Gershinsky, G.; Pour, N.; Aurbach, D. Mg rechargeable batteries: an on-going challenge. Energy Environ. Sci. 2013, 6, 2265-2279.

(8) Jayasayee, K.; Berthelot, R.; Lethesh, K.; Sheridan, E. Anode Materials for Rechargeable $\mathrm{Mg}$ Batteries. In Magnesium Batteries; Royal Society of Chemistry 2019; pp. 114-141.

(9) Saha, P.; Datta, M. K.; Velikokhatnyi, O. I.; Manivannan, A.; Alman, D.; Kumta, P. N. Rechargeable magnesium battery: Current status and key challenges for the future. Prog. Mater. Sci. 2014, 66, 186.

(10) Muldoon, J.; Bucur, C. B.; Oliver, A. G.; Sugimoto, T.; Matsui, M.; Kim, H. S.; Allred, G. D.; Zajicek, J.; Kotani, Y. Electrolyte roadblocks to a magnesium rechargeable battery. Energy Environ. Sci. 2012, 5, 5941-5950.

(11) Gaddum, L. W.; French, H. E. The electrolysis of grignard solutions1. J. Am. Chem. Soc. 1927, 49, 1295-1299.

(12) Shterenberg, I.; Salama, M.; Gofer, Y.; Levi, E.; Aurbach, D. The challenge of developing rechargeable magnesium batteries. MRS Bull. 2014, 39, 453-460.

(13) Yagi, S.; Tanaka, A.; Ichikawa, Y.; Ichitsubo, T.; Matsubara, E. Electrochemical stability of magnesium battery current collectors in a grignard reagent-based electrolyte. J. Electrochem. Soc. 2013, 160, C83.

(14) Gregory, T. D.; Hoffman, R. J.; Winterton, R. C. Nonaqueous Electrochemistry of Magnesium. J. Electrochem. Soc. 1990, 137, 775.

(15) Aurbach, D.; Lu, Z.; Schechter, A.; Gofer, Y.; Gizbar, H.; Turgeman, R.; Cohen, Y.; Moshkovich, M.; Levi, E. Prototype systems for rechargeable magnesium batteries. Nature 2000, 407, 724-727.

(16) Pour, N.; Gofer, Y.; Major, D. T.; Aurbach, D. Structural Analysis of Electrolyte Solutions for Rechargeable Mg Batteries by Stereoscopic Means and DFT Calculations. J. Am. Chem. Soc. 2011, $133,6270-6278$.

(17) Mohtadi, R.; Mizuno, F. Magnesium batteries: Current state of the art, issues and future perspectives. Beilstein J. Nanotechnol. 2014, 5, 1291-1311.

(18) Doe, R. E.; Han, R.; Hwang, J.; Gmitter, A. J.; Shterenberg, I.; Yoo, H. D.; Pour, N.; Aurbach, D. Novel, electrolyte solutions comprising fully inorganic salts with high anodic stability for rechargeable magnesium batteries. Chem. Commun. 2014, 50, 243245.

(19) Kim, H. S.; Arthur, T. S.; Allred, G. D.; Zajicek, J.; Newman, J. G.; Rodnyansky, A. E.; Oliver, A. G.; Boggess, W. C.; Muldoon, J. Structure and compatibility of a magnesium electrolyte with a sulphur cathode. Nat. Commun. 2011, 2, 427.

(20) Wang, F.-f.; Guo, Y.-s.; Yang, J.; Nuli, Y.; Hirano, S.-i. A novel electrolyte system without a Grignard reagent for rechargeable magnesium batteries. Chem. Commun. 2012, 48, 10763-10765.

(21) Guo, Y.-s.; Zhang, F.; Yang, J.; Wang, F.-f.; NuLi, Y.; Hirano, S.i. Boron-based electrolyte solutions with wide electrochemical 
windows for rechargeable magnesium batteries. Energy Environ. Sci. 2012, 5, 9100-9106.

(22) Zhao-Karger, Z.; Zhao, X.; Wang, D.; Diemant, T.; Behm, R. J.; Fichtner, M. Performance Improvement of Magnesium Sulfur Batteries with Modified Non-Nucleophilic Electrolytes. Adv. Energy Mater. 2015, 5, 1401155.

(23) Vinayan, B. P.; Zhao-Karger, Z.; Diemant, T.; Chakravadhanula, V. S. K.; Schwarzburger, N. I.; Cambaz, M. A.; Behm, R. J.; Kübel, C.; Fichtner, M. Performance study of magnesium-sulfur battery using a graphene based sulfur composite cathode electrode and a non-nucleophilic $\mathrm{Mg}$ electrolyte. Nanoscale 2016, 8, 3296-3306.

(24) Yu, X.; Manthiram, A. Performance enhancement and mechanistic studies of magnesium-sulfur cells with an advanced cathode structure. ACS Energy Lett. 2016, 1, 431-437.

(25) Du, A.; Zhang, Z.; Qu, H.; Cui, Z.; Qiao, L.; Wang, L.; Chai, J.; Lu, T.; Dong, S.; Dong, T.; Xu, H.; Zhou, X.; Cui, G. An efficient organic magnesium borate-based electrolyte with non-nucleophilic characteristics for magnesium-sulfur battery. Energy Environ. Sci. 2017, 10, 2616-2625.

(26) Zhang, Z.; Cui, Z.; Qiao, L.; Guan, J.; Xu, H.; Wang, X.; Hu, P.; Du, H.; Li, S.; Zhou, X.; Dong, S.; Liu, Z.; Cui, G.; Chen, L. Novel Design Concepts of Efficient $\mathrm{Mg}$-Ion Electrolytes toward HighPerformance Magnesium-Selenium and Magnesium-Sulfur Batteries. Adv. Energy Mater. 2017, 7, 1602055.

(27) Xu, H.; Zhang, Z.; Cui, Z.; Du, A.; Lu, C.; Dong, S.; Ma, J.; Zhou, X.; Cui, G. Strong anion receptor-assisted boron-based $\mathrm{Mg}$ electrolyte with wide electrochemical window and non-nucleophilic characteristic. Electrochem. Commun. 2017, 83, 72-76.

(28) Mohtadi, R.; Matsui, M.; Arthur, T. S.; Hwang, S.-J. Magnesium Borohydride: From Hydrogen Storage to Magnesium Battery. Angew. Chem. Int. Ed. 2012, 51, 9780-9783.

(29) Tutusaus, O.; Mohtadi, R.; Arthur, T. S.; Mizuno, F.; Nelson, E. G.; Sevryugina, Y. V. An Efficient Halogen-Free Electrolyte for Use in Rechargeable Magnesium Batteries. Angew. Chem. Int. Ed. 2015, 54, $7900-7904$

(30) Herb, J. T.; Nist-Lund, C. A.; Arnold, C. B. A Fluorinated Alkoxyaluminate Electrolyte for Magnesium-Ion Batteries. ACS Energy Lett. 2016, 1, 1227-1232.

(31) Herb, J. T.; Nist-Lund, C. A.; Arnold, C. B. A fluorinated dialkoxide-based magnesium-ion electrolyte. J. Mater. Chem. A 2017, 5, 7801-7805.

(32) Liu, T.; Shao, Y.; Li, G.; Gu, M.; Hu, J.; Xu, S.; Nie, Z.; Chen, X.; Wang, C.; Liu, J. A facile approach using $\mathrm{MgCl} 2$ to formulate high performance $\mathrm{Mg} 2+$ electrolytes for rechargeable $\mathrm{Mg}$ batteries. $\mathrm{J}$. Mater. Chem. A 2014, 2, 3430-3438.

(33) Barile, C. J.; Barile, E. C.; Zavadil, K. R.; Nuzzo, R. G.; Gewirth, A. A. Electrolytic conditioning of a magnesium aluminum chloride complex for reversible magnesium deposition. J. Phys. Chem. C 2014, 118, 27623-27630.

(34) Barile, C. J.; Spatney, R.; Zavadil, K. R.; Gewirth, A. A. Investigating the reversibility of in situ generated magnesium organohaloaluminates for magnesium deposition and dissolution. J. Phys. Chem. C 2014, 118, 10694-10699.

(35) Attias, R.; Salama, M.; Hirsch, B.; Goffer, Y.; Aurbach, D. Anode-Electrolyte Interfaces in Secondary Magnesium Batteries. Joule 2019, 3, 27-52.

(36) Ma, Z.; MacFarlane, D. R.; Kar, M. Mg Cathode Materials and Electrolytes for Rechargeable $\mathrm{Mg}$ Batteries: A Review. Batteries Supercaps 2019, 2, 115-127.

(37) Ha, S.-Y.; Lee, Y.-W.; Woo, S. W.; Koo, B.; Kim, J.-S.; Cho, J.; Lee, K. T.; Choi, N.-S. Magnesium (II) bis (trifluoromethane sulfonyl) imide-based electrolytes with wide electrochemical windows for rechargeable magnesium batteries. ACS Appl. Mater. Interfaces 2014, 6, 4063-4073.

(38) Wang, P.; NuLi, Y.; Yang, J.; Feng, Z. Mixed ionic liquids as electrolyte for reversible deposition and dissolution of magnesium. Surf. Coat. Technol. 2006, 201, 3783-3787.
(39) Su, S.; NuLi, Y.; Wang, N.; Yusipu, D.; Yang, J.; Wang, J. Magnesium Borohydride-Based Electrolytes Containing 1-butyl-1methylpiperidinium bis (trifluoromethyl sulfonyl) imide Ionic Liquid for Rechargeable Magnesium Batteries. J. Electrochem. Soc. 2016, 163, D682-D688.

(40) NuLi, Y.; Yang, J.; Wu, R. Reversible deposition and dissolution of magnesium from BMIMBF4 ionic liquid. Electrochem. Commun. 2005, 7, 1105-1110.

(41) Novák, P.; Imhof, R.; Haas, O. Magnesium insertion electrodes for rechargeable nonaqueous batteries-a competitive alternative to lithium? Electrochim. Acta 1999, 45, 351-367.

(42) Cheek, G. T.; O’Grady, W. E.; El Abedin, S. Z.; Moustafa, E. M.; Endres, F. Studies on the electrodeposition of magnesium in ionic liquids. J. Electrochem. Soc. 2008, 155, D91-D95.

(43) Kar, M.; Ma, Z.; Azofra, L. M.; Chen, K.; Forsyth, M.; MacFarlane, D. R. Ionic liquid electrolytes for reversible magnesium electrochemistry. Chem. Commun. 2016, 52, 4033-4036.

(44) Kar, M.; Tutusaus, O.; MacFarlane, D. R.; Mohtadi, R. Novel and versatile room temperature ionic liquids for energy storage. Energy Environ. Sci. 2018, 12, 566-571.

(45) Watkins, T.; Kumar, A.; Buttry, D. A. Designer ionic liquids for reversible electrochemical deposition/dissolution of magnesium. J. Am. Chem. Soc. 2016, 138, 641-650.

(46) Zhao, X.; Yang, Y.; NuLi, Y.; Li, D.; Wang, Y.; Xiang, X. A new class of electrolytes based on magnesium bis (diisopropyl) amide for magnesium-sulfur batteries. Chem. Commun. 2019, 55, 6086-6089.

(47) Fuller, J.; Carlin, R. T.; Osteryoung, R. A.; Koranaios, P.; Mantz, R. Anodization and Speciation of Magnesium in ChlorideRich Room Temperature Ionic Liquids. J. Electrochem. Soc. 1998, 145, 24-28.

(48) Bertasi, F.; Hettige, C.; Sepehr, F.; Bogle, X.; Pagot, G.; Vezzù, K.; Negro, E.; Paddison, S. J.; Greenbaum, S. G.; Vittadello, M.; di Noto, V. A key concept in magnesium secondary battery electrolytes. ChemSusChem 2015, 8, 3069-3076.

(49) Lin, P.-C.; Sun, I.-W.; Chang, J.-K.; Su, C.-J.; Lin, J.-C. Corrosion characteristics of nickel, copper, and stainless steel in a Lewis neutral chloroaluminate ionic liquid. Corros. Sci. 2011, 53, $4318-4323$.

(50) Zhao-Karger, Z.; Zhao, X.; Fuhr, O.; Fichtner, M. Bisamide based non-nucleophilic electrolytes for rechargeable magnesium batteries. RSC Adv. 2013, 3, 16330-16335.

(51) Keyzer, E. N.; Glass, H. F. J.; Liu, Z.; Bayley, P. M.; Dutton, S. E.; Grey, C. P.; Wright, D. S. Mg (PF6) 2-based electrolyte systems: understanding electrolyte-electrode interactions for the development of Mg-ion batteries. J. Am. Chem. Soc. 2016, 138, 8682-8685.

(52) Kang, S.-J.; Lim, S.-C.; Kim, H.; Heo, J. W.; Hwang, S.; Jang, M.; Yang, D.; Hong, S.-T.; Lee, H. Non-grignard and Lewis acid-free sulfone electrolytes for rechargeable magnesium batteries. Chem. Mater. 2017, 29, 3174-3180.

(53) Choi, S.-H.; Kim, J.-S.; Woo, S.-G.; Cho, W.; Choi, S. Y.; Choi, J.; Lee, K.-T.; Park, M.-S.; Kim, Y.-J. Role of $\mathrm{Cu}$ in Mo6S8 and $\mathrm{Cu}$ mixture cathodes for magnesium ion batteries. ACS Appl. Mater. Interfaces 2015, 7, 7016-7024.

(54) Liu, T.; Cox, J. T.; Hu, D.; Deng, X.; Hu, J.; Hu, M. Y.; Xiao, J.; Shao, Y.; Tang, K.; Liu, J. A fundamental study on the $[(\mu-\mathrm{Cl}) 3 \mathrm{Mg} 2$ (THF) 6]+ dimer electrolytes for rechargeable Mg batteries. Chem. Commun. 2015, 51, 2312-2315.

(55) Plommer, H.; Murphy, J. N.; Dawe, L. N.; Kerton, F. M. Morpholine-Stabilized Cationic Aluminum Complexes and Their Reactivity in Ring-Opening Polymerization of $\varepsilon$-Caprolactone. Inorg. Chem. 2019, 58, 5253-5264.

(56) Angell, M.; Pan, C.-J.; Rong, Y.; Yuan, C.; Lin, M.-C.; Hwang, B.-J.; Dai, H. High Coulombic efficiency aluminum-ion battery using an $\mathrm{AlCl} 3-$ urea ionic liquid analog electrolyte. Proc. Natl. Acad. Sci. 2017, 114, 834-839.

(57) Kiefer, J.; Fries, J.; Leipertz, A. Experimental vibrational study of imidazolium-based ionic liquids: Raman and infrared spectra of 1ethyl-3-methylimidazolium bis (trifluoromethylsulfonyl) imide and 1- 
ethyl-3-methylimidazolium ethylsulfate. Appl. Spectrosc. 2007, 61, 1306-1311.

(58) Fukutsuka, T.; Asaka, K.; Inoo, A.; Yasui, R.; Miyazaki, K.; Abe, T.; Nishio, K.; Uchimoto, Y. New Magnesium-ion Conductive Electrolyte Solution Based on Triglyme for Reversible Magnesium Metal Deposition and Dissolution at Ambient Temperature. Chem. Lett. 2014, 43, 1788-1790.

(59) Connell, J. G.; Genorio, B.; Lopes, P. P.; Strmcnik, D.; Stamenkovic, V. R.; Markovic, N. M. Tuning the Reversibility of $\mathrm{Mg}$ Anodes via Controlled Surface Passivation by $\mathrm{H} 2 \mathrm{O} / \mathrm{Cl}-$ in Organic Electrolytes. Chem. Mater. 2016, 28, 8268-8277.

(60) Merrill, L. C.; Schaefer, J. L. Conditioning-Free Electrolytes for Magnesium Batteries Using Sufone-Ether Mixtures with Increased Thermal Stability. Chem. Mater. 2018, 30, 3971-3974.

(61) Wall, C.; Zhao-Karger, Z.; Fichtner, M. Corrosion Resistance of Current Collector Materials in Bisamide Based Electrolyte for Magnesium Batteries. ECS Electrochem. Lett. 2014, 4, C8-C10.

(62) Cheng, Y.; Liu, T.; Shao, Y.; Engelhard, M. H.; Liu, J.; Li, G. Electrochemically stable cathode current collectors for rechargeable magnesium batteries. J. Mater. Chem. A 2014, 2, 2473-2477.

(63) Wan, L. F.; Perdue, B. R.; Apblett, C. A.; Prendergast, D. Mg desolvation and intercalation mechanism at the Mo6S8 chevrel phase surface. Chem. Mater. 2015, 27, 5932-5940.

(64) Cho, W.; Moon, B.; Woo, S. G.; Kim, J. H.; Park, M. S.; Kim, J. S.; Kim, H.; Kim, Y. J. Size effect of chevrel MgxMo6S8 as cathode material for magnesium rechargeable batteries. Bull. Korean Chem. Soc. 2015, 36, 1209-1214.

(65) Nelson, E. G.; Brody, S. I.; Kampf, J. W.; Bartlett, B. M. A magnesium tetraphenylaluminate battery electrolyte exhibits a wide electrochemical potential window and reduces stainless steel corrosion. J. Mater. Chem. A 2014, 2, 18194-18198.

(66) Lancry, E.; Levi, E.; Gofer, Y.; Levi, M.; Salitra, G.; Aurbach, D. Leaching chemistry and the performance of the Mo6S8 cathodes in rechargeable $\mathrm{Mg}$ batteries. Chem. Mater. 2004, 16, 2832-2838.

(67) Levi, E.; Lancry, E.; Mitelman, A.; Aurbach, D.; Ceder, G.; Morgan, D.; Isnard, O. Phase diagram of $\mathrm{Mg}$ insertion into chevrel phases, Mg x Mo6T8 ( $\mathrm{T}=\mathrm{S}, \mathrm{Se})$. 1. Crystal structure of the sulfides. Chem. Mater. 2006, 18, 5492-5503.

(68) Son, S.-B.; Gao, T.; Harvey, S. P.; Steirer, K. X.; Stokes, A.; Norman, A.; Wang, C.; Cresce, A.; Xu, K.; Ban, C. An artificial interphase enables reversible magnesium chemistry in carbonate electrolytes. Nat. Chem. 2018, 10, 532-539. 